\title{
Prinsip Komunikasi Islam Sebagai Etika Bermedia Sosial
}

\author{
Muhammad Ilmi Saggaf \\ UIN Sultan Aji Muhammad Idris Samarinda \\ Email: saggaf_m@yahoo.co.id \\ Muhammad Habibie \\ Universtas Darusalam (UNIDA) Gontor, Ponorogo \\ Email: muhammadhabibie685@gmail.com
}

\author{
Muhammad Wildan Arif Amrullah \\ Universtas Darusalam (UNIDA) Gontor, Ponorogo \\ Email: wildanarief49@gmail.com \\ Khairul Atqiya \\ Universtas Darusalam (UNIDA) Gontor, Ponorogo \\ Email: khairulatqiya@gmail.com
}

\begin{abstract}
In the era of globalization, the process of delivering a message and receiving it is so fast and easy. This is evidenced by the existence of social networking applications that are present on smartphones. The use of social media is very diverse, so that many people, ranging from ordinary people to journalists, can spread what they want. However, unfortunately, sometimes there are those who spread information on social media who do not pay attention to communication ethics, causing untrue news such as hoaxes, defamation, denunciation, etc. all of which are out of the realm of ethics. Whereas in Islam really uphold ethics in communication and prioritize ethics. And in principle, it leads people to experience a peaceful and comfortable life. So as media users must apply ethics, one of these ethics is the principle of Islamic communication, in which this communication has four main points, namely; honest, positive message, tabayyun and silm. Which Islamic communication has two main sources, namely the Al-Quran and As-Sunnah.

Keywords: Ethics, Islamic Communication, Social Media, Al-Qur'an and as-Sunnah
\end{abstract}

\begin{abstract}
Abstrak
Di era globalisasi proses penyampaian sebuah pesan dan menerimanya begitu cepat dan mudah. Hal ini terbukti dengan adanya aplikasi jejaring sosial yang hadir di smartphone. Dalam penggunaan bermedia sosial pun sangat beragam sehingga banyak dari masyarakat mulai dari orang-orang biasa sampai wartawan bisa menyebarkan apa yang di inginkan. Namun, sayangnya kadang ada yang menyebarkan informasi di media sosial tidak memperhatikan etika komunikasi sehingga menimbulkan berita-berita yang tidak benar seperti Hoax, pencemaran nama baik, mencela dsb yang semuanya itu keluar dari ranah etika. Padahal dalam Islam sangat menjunjung tinggi etika dalam komunikasi dan lebih mengedepankan adabnya. Dan dalam prinsipnya mengantarkan manusia untuk merasakan kehidupan yang damai dan nyaman. Maka sebagai pengguna media harus menerapkan etika, salah satu etika tersebut ialah prinsip komunikasi Islam, yang mana komunikasi ini memiliki empat poin utama yaitu; jujur, pesan positif, tabayyun dan silm. Yang mana komunikasi Islam ini memiliki dua sumber utama yaitu Al-Quran dan AsSunnah.
\end{abstract}

Kata Kunci: Etika, Komunikasi Islam, Media Sosial, al-Qur'an dan as-Sunnah

\section{PENDAHULUAN}

Media sosial saat ini telah dijadikan sebagai tempat untuk saling mendapatkan dan menyebarkan informasi. Hal ini terbukti dengan adanya aplikasi jejaring sosial yang hadir di smartphone. Dan penggunaan media sosial nampaknya telah menjadi bagian dari masyarakat. Seiring dengan kemudahan penyampain informasi, ide dan sikap kepada banyak orang yang diklasifikasikan dengan meggunakan mesin atau media massa seperti internet, radio, televisi dan 
majalah (Suprato: 2009, 17). Sebagaimana dikatakan oleh tokoh komunikasi Mc Luhan "The medium is the message" (media adalah pesan). Jadi pada dasarnya fungsi media sosial hanya untuk mempermudah penyampain sebuah pesan kepada komunikan.

Kebebasan dan kemudahan dalam menyebarkan informasi atau pesan dalam media sosial, dimana ketika penyedia informasi tidak datang dari wartawan, tetapi juga dari orang-orang biasa saja (Haryanto; 2014, 9). Banyak yang menyalahgunakan akan kebebasan bermedia tersebut, seperti penyebaran informasi pada sosial media yang tidak menggunakan etika, dan penyebaran berita Hoax, mencela dan sebagainya (Morisan: 2013, 493). Maka yang penting dan harus diperhatikan dalam bermedia sosial ialah etika.

Islam sangat menjunjung tinggi terhadap etika. Sebagaimana sabda Nabi Muhammad Saw, sesungguhnya aku diutus untuk menyempurnakan Akhlak yang baik (Hambal: 1999, 512). Dan dalam prinsip komunikasi Islam ialah mengantarkan manusia untuk merasakan kehidupan yang damai dan nyaman (silm) (Hefni : 2015, 70). Adapun saling merendahkan, mencela serta berbagi perbuatan negatif lainnya maka bukan termasuk dari prinsip komunikasi Islam. Maka dalam hal beretika Islam sengat memperhatikan hal tersebut.

Makna dari komunikasi Islam, ialah komunikasi yang dibangun di atas prinsip-prinsip Islam yang memiliki roh kedamain, keramahan dan keselamatan (Hefni: 2015, 14). Kepedulian Islam dalam bidang ini tergambar dari banyak istilah yang terkait dengan komunikasi. Seperti firman Allah pada surah Al-Hujurat ayat 6 (QS Al-Hujurat). Dalam surah ini jelas Allah menjelaskan bagaimana cara berkomunikasi terutama dalam menerima sebuah pesan dan menyebarkannya. Jadi dalam komunikasi Islam ini ialah komunikasi yang dipandu oleh agama yang sesuai dengan alur yang ditentukan Allah.

Maka dalam penggunaan media sosial harus disertai etika. Karena melihat kebebasan dan kemudahan mengakses nya sehingga banyak dari orang-orang yang menyalahgunakannya, maka dari itu Islam menawarkan komunikasi Islam, yang mana komunikasi Islam ini ialah konsep komunikasi yang berdasarkan Agama Islam, yang sangat menjaga dalam etika dalam berkomunikasi.

\section{PEMBAHASAN}

\section{A. DEFINISI}

\section{Pengertian Komunikasi Islam}

Fungsi Al-Quran diturunkan kedunia sebagai penuntun dan penunjuk kehidupan bagi ummat manusia untuk mengelola alam serta mengatur tatanan kehidupan (Prayogo, 2019; 19-20). Dan Al-Quran sebagai firman Tuhan yang diwahyukan, merupakan penuntun dari kebenaran dan dasar bagi jalan hidup yang Islam. Kitab yang merupakan petunjuk yang menuju kepada 
perkembangan kepribadian manusia dan peraturan sosial atas dasar keesaan tuhan (Sardar, 1991; 11).

Dalam perspektif Islam, komunikasi merupakan bagian yang tidak dapat dipisahkan dalam kehidupan manusia karena segala gerak dan langkah manusia selalu disertai dengan komunikasi. Komunikasi yang dimaksud adalah komunikasi yang islami, yaitu komunikasi yang berakhlak al karimah atau komunikasi yang beretika.

Berbicara komunikasi islam tentu komunikasi yang dibangun menurut agama Islam. Komunikasi Islam ialah komunikasi yang dibangun atas prinsip-prinsip Islam yang memilki roh kedamaian, keramahan dan keselamatan. Dalam komunikasi islam ialah upaya membangun hubungan dengan diri sendiri, sang pencipta dan dengan sesama untuk menghadirkan kedamaian dan ketentraman.

Tindakan apapun dalam komunikasi yang membuat hati seseorang menjadi rusak atau menjadi sakit dan luka. Seperti yang sering terjadi dimedia sosial tentang pernyataan yang merendahkan suatu pihak. Maka hal tersebut bertentangan dengan komunikasi Islam. Kepedulian Islam tentang hal ini banyak tergambar dari banyak istilah dalam Al-quran, yang terkait dengan komunikasi (Hefni, 2015; 15).

Sebagai sebuah ilmu, komunikasi Islam memiliki sumber utama yaitu Al-quran dan Assunnah. Selain dari sumber utama tersebut ada ilmu-ilmu pendukung untuk memahaminya, kitabkitab para ulama baik yang klasik maupun kontemporer juga banyak bisa menjadi bahan baku yang bisa membangun ilmu komunikasi Islam. Maka dari dua sumber utama inilah ilmu Komunikasi Islam berkembang (ibid). Maka dalam komunikasi Islam tidak setidaknya ada empat poin yang sangat penting: 1) Jujur, 2) Pesan Positif, 3) Tabayyun, 4) Silm.

\section{Pengertian Etika}

Kata bahasa Indonesia etika (bahasa Arab akhlaq, bahasa latin, ethica, Inggris ethics, Prancis ethique, Belanda ethiek, Jerman ethic) secara etimilogis diturunkan dari kata Yunani, ethos, yang berarti 'adat istiadat' atau 'pola kebiasaan berprilaku'. Kata bahasa latin mos, moris mempunyai arti yang sama. Jadi pada dasarnya etika memiliki perbedaan dalam penyebutannya akan tetapi dalam segi makna semua sama. Dan secara umum tata cara pergaulan, aturan prilaku, adat kebiasaan manusia dalam bermasyarakat dan menentukan nilai baik dan tidak, disebut etika (Kismiyati, 2010; 59).

Dalam kehidupan bermasyarakat terdapat suatu sistem yang mengatur tata cara manusia bergaul. Tata cara pergaulan untuk saling menghormati biasa dikenal dengan etika atau sopan santun. Tata cara pergaulan bertujuan untuk menjaga kepentigan komunikator dan komunikan 
agar merasa tenang, tentram dan terlindungi dari pihak lain yang merugikan dan keluar dari norma-norma etika.

Etika berawal dari kegiatan berfilsafat atau berpikir yang dilakukan manusia. Karena itu, etika sebenarnya adalah bagian dari filsafat; etika lahir dari filsafat. Etika dimulai bila manusia merefleksikan unsur-unsur etis dalam pendapat-pendapat spontan seseorang (. Bertens, 1993; 13). Kebutuhan akan refleksi itu akan dirasakan, antara yang lain karena tidak jarang pendapat etis seseorang berbeda dengan orang lain. Untuk itu diperlukannya etika, yaitu untuk mencari tahu apa yang harus dilakukan manusia. Etika mengkaji mengapa seseorang harus mengikuti moralitas tertentu, atau bagaimana seseorang mengambil sikap yang bertanggung jawab dalam berhadpan dengan berbagi moralitas. Jadi etika dalam hal ini termasuk dalam filsafat moral.

Secara makna moralitas memiliki perbedaan etika. Moralitas berarti 'nilai-nilai dan normanorma moral seseorang atau suatu masyarakat' dengan nilai moral dimaksudkan sesuatu yang berguna bagi manusia, individu atau kelompok. Sedangkan dengan norma moral dimaksudkan aturan tentang bagaimana manusia harus hidup supaya menjadi baik sebagai manusia. Nilai dan norma moral terhimpun didalam apa yang disebut moralitas. Berarti moralitas merupakan sistem nilai dan norma bagaimana manusia harus bertindak agar disebut sebagai manusia. Jadi dalam segi makna etika memiliki perbedaan, jadi etika ialah sebagai salah satu dari cabang filsafat yang berbicara tetntang nilai dan norma moral yang menentukan prilaku manusia dalam bersosial (Pangalila, 2006; 3).

Maka dalam bermedia sosial harus disertai dengan beretika sebagaimana telah dijelaskan mengenai etika diatas bahwasanya etika ialah suatu ilmu yang berbicara tentang nilai dan norma moral. Maka jika sebuah etika diterapkan dalam bermedia sosial, maka kecil kemungkinan terjadi hal-hal yang negatif dalam media tersebut.

\section{Pengertian Media Sosial}

Berbicara tentang komunikasi massa maka tidak terlepas dengan penggunaan media massa saat komunikasi itu berlangsung. Sebagaimana dikemukakan oleh ahli komunikasi Bittner yakni "mass communication is massages communicated through a mass medium to a large number of people" (Bittner, 1980; 37) (komunikasi massa adalah pesan yang dikomunikasikan melalui media massa pada sejumlah besar orang.) dari definisi ini bisa dikatakan bahwa komunkasi massa itu harus menggunakan media massa. Jadi sekalipun komunikasi itu disampaikan kepada khalayak banyak, seperti rapat akbar dilapangan luas yang dihadiri oleh ribuan orang, jika tidak menggunakan media massa, maka itu bukan termasuk komunikasi massa (Ardianto, Lukiati Kumala, 2014; 3). 
Istilah media bisa dijelaskan sebagai alat komunikasi. Sebagaimana dijelaskan oleh tokoh komunikasi Wilbur Schramm media merupakan teknologi yang dapat membawa pesan sehingga mempercepat dan mempermudah pembelajaran (Schramm, 1995; 2). Dari penjelasan tadi bisa di lihat bahwasanya media ialah sebuah alat komunikasi. Beberapa definisi yang ada memiliki kecendrungan yang sama bahwa ketika di sebutkan kata "media", yang muncul bersamaan dengan itu adalah sarana disertai dengan teknologi. Seperti internet yang merupakan reprentasi dari media online atau didalam jeringan. Jadi pada dasarnya media merupakan teknologi yang mempermudah penyampain sebuah informasi.

Beragam media bisa dibuat untuk melihat bagaimana media itu. Ada yang membuat kriteria media itu berdasarkan teknologinya. Seperti media elektronik yang dihasilkan dengan perangkat elektronik, dan ada juga yang menuliskannya berdasarkan bagaimana pesan itu disebarkan. Contohnya media penyiaran (broadcast) di mana media merupakan pusat dari produk pesan, seperti televisi, dan pesan itu disebarkan serta bisa dinikmati oleh siapa saja asal memiliki pesawat televise (Nasrullah, 2016; 3).

Media massa memiliki varian bentuk yang berbeda satu dan yang lainnya. Dalam hal ini media massa dibagi menjadi dua jenis yaitu media cetak dan media elektronik. Media cetak ialah media yang mengkomunikasikan sebuah informasi menggunakan surat kabar majalah dan sebagainya. Adapun media elektronik komunikasi massa yang menggunakan elektronik seperti Radio, televisi dan internet. Jadi dari dua jenis inilah sebuah komunikasi massa itu berlangsung (Ardianto, Lukiati Kumala, 2014; 3).

Setelah membahas tentang pengertian dan bentuk komunikasi massa maka dalam hal ini media sosial termasuk media massa. Dilihat dari sifat media sosial tersebut dari proses komunikasi yang berlangsung hingga adanya media yang ikut andil dalam peroses tersebut maka jelas media sosial termasuk komunikasi massa.

Dalam memahami media massa, maka harus pula mengetahui cara kerja media massa tersebut. Media massa memiliki beberapa cara kerja. Pertama; menginformasikan, yaitu menyebarluaskan informasi kepada masyarakat, seperti berita. Kedua; mengawasi, seperti menyiarkan informasi yang menunjukkan kekeliruan yang terjadi ditengah masyarakat. Ketiga; mendidik, dalam media tersebut terdapat unsur-unsur pendidikan, seperti mendidik masyarakat agar tidak membuang sampah sembarangan. Keempat; menghibur, menayangkan sesuatu yang lucu seperti film, kartun dan sebagainya. Kelima; mempengaruhi, misalnya seperti tajuk rencana yang ditulis untuk mempengaruhi pandangan orang terhadap satu permasalahan aktual yang biasanya mengundang berbagai pandangan. Maka dari kelima cara inilah media massa memiliki cara kerja (Iriantara, 2011;154). 
Kata "sosial" dalam media sosial secara terori mestinya dekat oleh ranah sosiologi. Inilah menurut Fuchs ada beberapa pertanyaan dasar ketika melihat sosial, misalnya terkait dengan informasi dan kesadaran. Ada pertanyaan dasar, seperti apakah individu itu baru adalah manusia yang selalu berkarakter sosial atau individu, itu baru dikatakan sosial ketika ia secara sadar melakukan intraksi. Bahkan, dalam teori sosiologi disebutkan bahwa media pada dasarnya adalah sosial karena media merupakan bagian dari masyarakat dan aspek dari masyarakat yang di presentasikan dalam bentuk perangkat teknologi yang digunakan (Funch, 2017; 37).

Setelah membahas tentang makna dari kata media yang memiliki makna teknologi dan sosial yang artinya adanya interaksi, bisa dikatakan bahwa definisi media sosial adalah saluran di internet yang memungkinkan penggunanya mempresentasikan dirinya maupun berinteraksi, bekerja sama, berbagi, berkomunikasi dengan penggunaan yang lain, dan membentuk ikatan sosial secara virtual (Nasrullah, 2016; 11). Seperti dalam facebook seseorang bisa dengan bebas menginformasikan apapun tentang dirinya maupun tentang orang lain, tetapi harus disertai dengan adanya jaringan Internet sehingga media sosial tersebut bisa diakses.

Berbicara media sosial tentu media tersebut memiliki beberapa model. Setidaknya ada enam katagori besar untuk melihat pembagian media sosial yakni:

1. Media jejaring sosial (social networking).

2. Jurnal online (blog).

3. Jurnal online sederhana atau mikroblog (micro blogging).

4. Media berbagi (media sharing).

5. Penanda sosial (social bookmarking).

6. Media konten bersama Wiki (Nasrullah, 2016; 39).

Pembagian jenis media sosial kedalam katagori ini merupakan upaya untuk melihat bagaimana jenis media sosial itu. Bukan berarti hanya terbatas pada pembagian ini apalagi melihat perkembangan platform diinternet dan aplikasi perangkat telpon genggam, seperti aplikasi yag berbasis Android dan IOS, namun secara dasar dan teori, semestinya harus ada landasan awal untuk melihat jenis-jenis media tersebut (Apriadi, 2013; 78).

Media sosial memiliki ciri-ciri sebagai berikut; 1) pesan yang disampaikan tidak hanya untuk satu orang, tetapi bisa keberbagai banyak orang, contohnya melalui Sms ataupun internet; 2) pesan yang disampaikan bebas, tanpa harus melalui "Gatekeper"; 3) pesan yang disampaikan cendrung lebih cepat dibanding media lainnya; 4) penerima pesan yang menentukan waktu intraksi (Hikmat, 2018; 40). Maka jika media tersebut memiliki ciri-ciri yang telah disebutkan maka besar kemungkinan media tersebut ialah media sosial. 
Media Sosial ialah sebuah media online, sebagaimana telah dijelaskan diatas. Dengan tujuan memudahkahkan dalam penyampain sebuah informasi, mau itu berbentuk Blog, Jejaring sosial, dunia virtual, Wiki dan sebagainya, yang mana media tersebut yang paling umum digunakan oleh masyarakat diseluruh dunia (Mulyanam, 2014).

\section{B. DAMPAK KEBEBASAN DALAM BERMEDIA SOSIAL}

Seiring dengan berjalannya waktu maka teknologi juga semakin berkembang pesat. Saat ini hampir sebagian orang bisa saling berbagi informasi melelui media sosial, sebab dengan internet maka akan lebih menghemat waktu dan biaya. Dan penggunaannya terbilang bebas, asal seseorang mempunyai jaringan internet maka media sosial itu bisa diakses dengan mudah.

Media sosial yang muncul belakangan ini dalam rupa seperti Facebook, Twitter, Instagram, Whatsapp, Line dan aplikasi lainnya. Tidak sedikit permasalahan yang terjadi akibat kurangnya masyarakat dalam beretika. Banyak memiliki dampak-dampak yang negatif karena melihat kebebasan dalam pengaksesannya dan kemudahan mengaksesnya. Dalam era ketika penyedia informasi tidak datang dari wartawan, tetapi juga dari orang-orang biasa, maka seseorang harus mempertimbangkan informasi tersebut. Terkadang sangking banyaknya, seperti menghadapi tsunami informasi, banyak contoh yang sudah ditemui dimana sebuah informasi yang tersebar begitu saja tanpa divertifikasi terlebih dahulu seperti yang baru baru saja terjadi. "Pihak BMKG memprediksi akan terjadi kemarau panjang pada tahun 2019-2022: Keluarnya Dajjal sangat dekat"( infobmkg; 2018) informasi ini ialah berita Hoax yang sibarkan melalui media.dan juga yang hangat baru-baru ini sebuah berita tentang ditangkapnya Habib Rizieq Syihab di Arab Saudi, padahal berita yang benar ialah kepolisian mengintrogasi guna penyelidikan (Youtube;2018). Maka dari berita tersbut memiliki dampak yang begitu besar khususnya ummat Islam. Dan banyak lagi contoh-contoh yang disebabkan kebebasan bermedia sosial (Haryanto; 2014, h 10). Dan seperti pencemaran nama baik, fitnah, hinaan didunia maya. ${ }^{1}$ Maka dari itu penting kiranya sebagai pengguna media mengutamakan etika dalam berkomunikasi.

Berita hoax saat ini sungguh sangat memenuhi dunia internet, khusus media sosial. banyak berita-berita hoax yang disebarluaskan, seperti yang baru-baru saja yang dikutip dari barita hoax bulanan, yang isinya tentang gunung meletus diManado. Dan banyak lagi berita hoax yang dipaparkan Kominfo dalam berita Hoax bulanan. Melihat kemudahan dalam mengaksesnya maka besar peluang berita hoax menyebar di media sosial(Sirikit Syah ;2011, h. 53).

1 Sirikit Syah 2011, Rambu rambu Jurnalistik dari undang-undang hingga hati nurani. (Yogyakarta: Pustaka pelajar, 2013) hal.53. 
Prinsip Komunikasi Islam Sebagai Etika Bermedia Sosial

Muhammad Ilmi Saggaf, Muhammad Wildan Arif Amrullah, Muhammad Habibie, Khairul Atqiya

Belakangan ini muncul budaya share. Seperti sebuah pesan yang diujungnya ada sebuah ancaman bagi yang tidak mengsharenya. Fenomena budaya share,( Sirikit Syah ;2011, h. 530) makin menggila terutama ditahun 2018, pada saat menjelang pilpres. Beberapa figur ternama pendukung capres tertentu dengan atau tanpa sengaja memelintir berita, mengomentari lalu menjatuhkan lawan politiknya. Pola-pola pemberitaan Hoax pun sering bertebaran dimedia sosial, dengan membuat berita bombastis untuk menarik minat baca. Terkadang judul dan isi tidak sinkron, celakanya banyak pengguna media sosial dinegeri ini malas membaca dan cendrung mudah terprovokasi, oleh judul yang tampak menarik dan langsung membagikan laman tersebut.

Pada saat melakukan komunikasi dalam media sosial, tidak sedikit cendrung melupakan etika dalam berkomunikasi. Hal ini dibuktikan dengan banyaknya kata kata kasar yang kerap muncul dalam percakapan,baik disengaja atau tidak. Contoh kasus yang sering terjadi pada media facebook yang mana pada saat ini lagi musim perpolitikan mendekati pemilihan presiden di tahun 2019, yang satu pihak membela pasangan A dan pihak yang lain membela pasangan B. dalam pemebelaan mereka kerap terjadi perang komentar dalam facebook tersebut sehingga tidak sedikit terucap kata-kata yang tidak beretika(Tamburaka; 2013, 221). Seperti kata-kata yang mengarah kepada pencemaran nama baik, bahkan ada yang menyelipkan berita hoax di kolom komentar. Maka dari itu dalam bermedia sosial harus disertai etika dalam penggunaanya.

Media sosial seakan menjadi tempat menumpahkan cerita segala aktifitas, luapan emosi dalam bentuk tulisan atau foto yang tidak jarang mengesampingkan etika yang ada, media sosial seakan tidak lagi menjadi media informasi melainkan berbagi sensasi. Jika kemajuan teknologi tidak dibarengi dengan kemajuan berpikir, yang ada kemajuan teknologi tersebut berbanding terbalik dalam hal pola pikir, terutama dalam etika berkomunikasi

Kemudahan dalam mengakses media sosial membuat banyak orang melupakan etika, etika yang harusnya dianggap penting, akan tetapi belakangan ini malah terjadi penurunan dalam hal etika, bisa dilihat dalam media sosial berapa banyak pengguna melontarkan kata-kata yang keluar dari etika. Maka tanpa disadari banyak yang lupa akan etika karna kemudahan dalam mengakses media sosial(Mursitom; 2006, 47).

\section{PRINSIP KOMUNIKASI ISLAM SEBAGAI ETIKA BERMEDIA SOSIAL}

Dalam komunikasi Islam tentu memiliki prinsip-prinsip yang berhubungan dengan komunikasi. Salah satu konsep komunikasi Islam ialah komunikasi yang bertujuan untuk saling mengenal antara manusia untuk mewujudkan semangat taqwa. Allah menciptakan manusia dengan berbagai latar belakang, baik bahasa, adat, suku bangsa, dan Agama. Maksud dari keragaman itu adalah agar manusia bisa saling mengenal. Dengan keberagaman yang sungguh 
indah, ibarat bunga yang berwarna-warni di sebuah taman yang luas. Fenomena keberagaman ini disebutkan dalam firman Allah SWT dalam surah al-hujurat (13) (Qs Al-hujurat (13). Jadi dalam komunikasi Islam sangat keberagaman sesama manusia sangat diperhatikan dalam menjalani kehidupan sosial.

Al-Qurthubi menyebutkan sebab turunnya ayat diatas. Ialah karena sikap Atab bin Usaid yang tidak bisa menerima kenyataan bahwa Bilal yang berkulit hitam berasal dari kalangan budak bisa naik ke Ka'bah. Padahal ka'bah pada masa jahiliyah adalah hak istimewa para bangsawan Makkah(Abu Abdillah; 1964, 341). Dari sebab inilah ayat terebut turun, maka dalam hal ini semakin matang cara berpikirnya dan ini senada dengan prinsip komunikasi yang disebutkan diatas (Hefni; 2015, 68). Yaitu saling menghargai perbedaan.

Komunikasi antar manusia merupakan aktifitas menyampaikan dan menerima pesan dari komunikator kepada komunikan. Saat berlangsung komunikasi, proses pengaruh dan mempengaruhi terjadi. Disamping itu, komunikasi bertujuan untuk saling mengenal, berbagi informasi, menghibur, memecahkan masalah dan sebagainya. Disamping tujuan yang baik, komunikasi juga dapat dipakai untuk saling memfitnah, melemahkan, adu domba, meruntuhkan status dan sebagainya. Karena muara semua tujuan komunikasi ialah pertukaran pesan, maka membangun komunikasi yang bertujuan untuk menciptakan suasana yang sehat adalah bagian yang tidak terpisahkan dari Islam.

Komunikasi memiliki kekuatan dalam menggiring opini public. Hal ini sebagaimana di jelaskan dalam hadis Nabi "Dari Abdullah bin Umar r.a, telah datang dua orang dari masyrik, lalu keduanya berpidato. Orang-orang terkagum kagum dengan penjelannya. Lalu Rasulullah SAW bersabda :"sesungguhnya di antara pesan yang terucap itu adalah bius" (Muhammad Bin Ismail;1422, h5146). Dari sinilah dalil bahwasanya komunikasi memilki kekuatan dalam menggiring opini.

Menurut Ibnu Hajar, 'bayan' itu terbagi dua. Pertama, penjelasan maksud sebenanrnya;kedua, memperindah retorika sehingga hati para pendengar terpesona mendengarkannya. Seni menyampaikan pesan disebut oleh Nabi sebagai sihir kerena bisa mengalihkan perhatian pendengar kepada makna yang diinginkan oleh pembicara.

Etika komunikasi menurut pandangan Islam cukup luas, akan tetapi empat poin utama dalam komunkasi islam yang sangat penting. Pesan yang positif, jujur, tabayyun, dan silm. (yaitu menebarkan kedamain dan ketentraman). Dari keampat poin inilah sebuah komunikasi dan pesan akan berlangsung secara Islami dan beretika, yang berdasarkan Al-Quran dan As-Sunnah (Khalil; 2007,h 26). Besarnya pengaruh komunikasi terhadap penggiringan opini. Maka perlu ditimbang sebelumnya, sebelum mengkomunikasikan sebuah pesan. Terutama diera globalisasi ini yang 
mana sebuah informasi menyebar dimana-mana tanpa bisa dipertanggung jawabkan, maka poinpoin inilah yang terpenting dalam bingkai ilmu komunikasi dalam Islam.

\section{a. Jujur}

Komunikasi Islam tunduk dengan sumber utama ajaran Islam. Yaitu Al-qurran dan Assunnah. Dari dua sumber inilah prinsip-prinsip dasar ilmu komunikasi Islam diambil. Dengan memahami prinsip-prinsip dasar komunikasi dalam Islam, maka seseorang akan memahami rambu-rambu yang membantunya dalam berkomunikasi sesuai dengan aturan umum ajaran Islam. Prinsip Islam ini berlaku umum untuk segala bentuk komunikasi dengan sesama manusia.

Diantara prinsip komunukasi Islam ialah Jujur. Lisan bisa membunuh karekter seseorang bahkan bisa menimbulkan pertumpahan darah. Karena itu kejujuran dalam menyampaikan pesan adalah prinsip mendasar dalam komunikasi Islam. Tidak tegaknya prinsip ini akan berakibat fatal buat kehidupan manusia.

Dalam bersosialisasi, orang yang memiliki akhlak berbeda dengan orang biasa. Tidak mudah memutar balikkan fakta. Karena, memutar balikkan fakta ialah fitnah yang membuat suasana dan menimbulkan ketidakharmonisan hubungan. Bukan sekedar itu, akan terjadi pada suatu waktu, orang yang baik disulap menjadi penghianat, dan penghianat dipoles sedemikian rupa menjadi pahlawan. Selain itu, hubungan dengan kerabat semakin renggang dan komunikasi dengan tetangga tidak harmonis. Sebagaimana dalam hadits:

$$
\text { تذكن أبي هريرة عن النبي صلى الله عليه و سلم قال : ( أتدرون ما الغيبة ) ؟ قالوا : الله ورسوله أعلم قال : ( أن }
$$

Dalam hadis sungguh jelas bahwasanya memutar balikkan fakta sungguh perbuatan yang sangat dilarang dalam Islam. Maka dari itu kejujuran sangatlah penting dalam etika komunikasi, terutama diera milenial ini yang sangat banyak sekali para komunikator yang memutar balikkan fakta yang disebar melalui media sosial.

Tidak berdustapun menjadi hal sangat ditekankan dalam Islam, dusta berarti memanipulasi informasi sehingga pesan tidak sampai semestinya. Sebagaimana ditekankan dalam hadits:

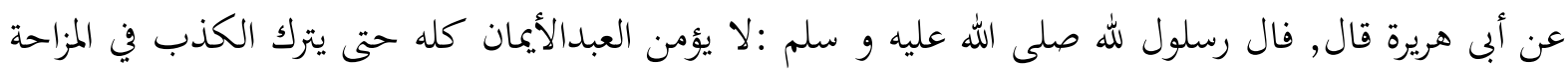

$$
\text { ويترك المراء وإن كان صادقا }
$$


"Dari Abu Hurairah berkata, Rasullah SAW bersabda : tidak akan sempurna iman seseorang sehingga meninggalkan dusta menskipun saat canda, dan meninggalkan pertengkaran meskipun berada di pihak yang benar". Dalam hal ini dusta dapat menimbulkan informasi yang masuk kepada seseoranng menjadi cacat. Akibat dari informasi yang keliru adalah persepsi yang tidak benar. Dari persepsi yang tidak benar yang akan menimbulkan tindakan seseorang menjadi negatif.

\section{b. Pesan Positif}

Dan juga termasuk dari prinsip komunikasi Islam ialah pesan yang positif yang didalamnya tidak terkandung hal-hal yang merugikan salah satu pihak. Pesan positif sangat berpengaruh bagi kebahagian seseorang dalam kondisi apapun dia berada. Beberapa hadis Nabi tentang hal ini:

$$
\text { عن أنس بن مالك : أن النبي صلى الله عليه و سلم كان يع حبه إذا خرج لحاجة أن يسمع ياراش يا نجيح }
$$

"Dari Anas bin malik, sesungguhnya Nabi SAW senang kalau beliau keluar untuk suatu urusan mendengarkan orang-orang yang mengucapkan: semoga selalu dalam tuntunan, semoga selalu sukses" ( Muhammad bin Isa; 213) dalam hadis ini menerangkan betapa berpengaruhnya perkataan yang positif terhadap komunikan, terutama jika etika seperti ini diaplikasikan dalam etika bermedia sosial tentu akan menambah keharmoniasan antara sesama manusia.

\section{c. Tabayyun}

Islam pun sangat menekankan Tabayyun dalam proses komunikasi. Pengertian tabayyun dalam surah al-hujurat (6).

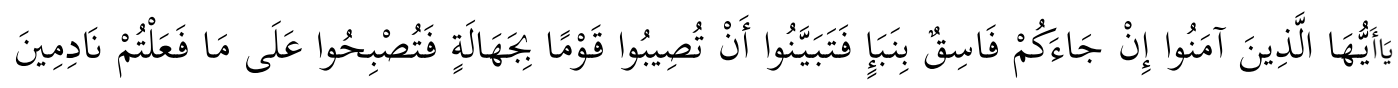

"hai orang orang yang beriman, jika datang kepadamu orang fasik membawa suatu berita, maka periksalah dengan teliti, agar kamu tidak menimpakan suatu musibah kepada suatu kaum tanpa mengetahui keadannya yang menyebabkan kamu menyesal atas perbuatanmu itu"

jika dilihat dalam tafsir Al-quran department Agama 2004. ( Departemen Agama RI; 2004, h 466)) Kata itu merupakan fiil amr untuk jamak, dari kata kerja tabayyana. Masdarnya attabayyun,yang atinya adalah mencari kejelasan hakikat sesuatu atau kebenaran suatu fakta dengan teliti, seksama dan hati-hati. Perintah untuk tabayyun merupakan perintah yang penting. Terutama pada akhir-akhir ini dimana media menjadi tempat penyebaran informasi yang tidak valid.maka dari itu Allah memerintahkan untuk bersikap hati-hati dalam menerima dan menyebarkan sebuah informasi.

Dalam tafsir Ibnu katsir pun manusia diperintahkan menelaah sebuah informasi. Manusia diperintahkan untuk mencari kebenaran akan sebuah pesan, apakah pesan tersebut termasuk 
informasi yang tidak benar atau informasi yang mengandung hal-hal yang negatif. Maka jelas sekali dalam ayat ini Allah menekankan tabayyun dalam hal menyebarkan sebuah pesan. Hal ini dipertegas dalam hadits yang diriwayatkan shahih muslim,

$$
\text { كفى بالمرء كذبا أن يحدث بكل ما سمع }
$$

"Cukuplah dikatakan pembohong orang yang mengucapkan semua yang dia dengar"

Maka dalam proses komunikasi, tabayyun sangat diperhatikan. Dalam memberikan informasi dan berkomunikasi, islam sangat menekankan kepada komunikator agar tetap pada dalam bingkai etika. Terutama dalam penggunaan media. Hal ini senada dengan fatwa Majelis Ulama Indonesia nomer 24 tahun 2017 tentang hukum dan pedoman bermuamalah melalui media sosial, haram menyebarkan berita hoax, atau berita bohong walau tujuan nya baik seperti info tentang kematian orang yang masih hidup.( Komisi Fatwa Majlis Ulama Indonesia2017). Sebagaimana Agama yang kaffah dan sempurna, Islam telah mengatur rambu-rambu ketika seseorang akan memberikan informasi.

\section{d. Silm}

Dan juga dalam perspektif Islam, akhir dari proses komunikasi ialah mengantarkan manusia untuk merasakan kehidupan yang damai dan nyaman (silm). Dan bukan sebaliknya seperti dalam penyalahgunaan media yang mana disebarkan dengan tujuan membuat takut seperti; berita bencana yang bakal terjadi, dan menghina dengan membuat status disosial media. Dengan tujuan menyinggung seseorang dan sebagainya. Diantara bukti menyatunya prinsip silm dalam komunikasi ialah celaan Allah SWT terhadap setiap orang yang suka mengumpat dan mencela baik dengan kata-kata maupun dengan perbuatan. Dalam surrat al-humazah ayat 1. Meskipun para ulama tafsir berbeda dalam mentafsirkan kata humazah dan lumazah, tetapi secara umun, makna dari kata ini adalah menghina dan merendahkan.

Dan di sisi lain nabi juga memberikan isyarat bahwasanya menebarkan kedamaian dan ketentraman ini sangat ditekankan. Dalam hal ini nabi mengisyaratkannya bahwa tidak beriman orang yang tetangganya tidak nyaman dengan gangguannya, sebagaimana dalam hadis

$$
\text { لا يد خل الجنة من لا يأمن جاره بواءقه }
$$

“tidak masuk surga orang yang tetangganya tidak aman dari gangguannya”. Disini tetangganya saja sangat dijaga akan ke tentraman hidupnya, apalagi lebih dari itu, seperti penyebaran berita Hoax yang biasa isinya seseuatu yang membuat yang menerima pesan tersebut takut dan gelisah, yang disebarkan dalam media sosial. Yang penggunanya sangat banyak, 
sebagaimana data dari Kominfo, yang mana menurut kominfo penggunan internet mencapai 63 juta jiwa.

Semangat silm inilah yang mengantarakan yang bisa mengantarkan islam mampu merealisasikan cita-citanya untuk menjadi rahmatan lilalamin. Adapun saling merendahkan, memfitnah orang, melakukan adu-domba serta berbagi perbuatan yang negatif lainnya yang tidak sejalan dengan semangat dasar komunikasi Islam (Hefni; 2015, h 70).

\section{KESIMPULAN}

Berbicara media tentu tidak lepas dengan proses komunikasi. Komunikasi ialah suatu proses penyampain sebuah pesan dan menerimanya, diera milenial sekarang media semakin canggih perkembangannya, hal ini terbukti dengan adanya smartphone yang menjadi sarana oleh media tersebut. Maka dengan adanya perkembangan ini sungguh sangat mempermudah proses komunikasi.

Media sosial saat ini sungguh menjadi kebutuhan masyarakat Dilihat dari kemudahan dalam mengaksesnya. Sebagaimana data dari Kominfo bahwasanya pengguna media Internet mencapai 63 juta jiwa. Terlepas dari itu banyak hal-hal yang terjadi dimedia sosial yang keluar dari ranah etika. Seperti penyebaran berita Hoax, pencemaran nama baik, mencela dan sebagainya. Yang semua ini keluar dari ranah etika.

Maka sebagai pengguna media harus menerapkan etika, salah satu etika tersebut ialah prinsip komunikasi Islam, yang mana komunikasi ini memiliki 4 poin utama yaitu; jujur, pesan positif, tabayyun dan silm. Yang mana komunikasi Islam ini memiliki dua sumber utama yaitu Al-Quran dan As-Sunnah.

\section{Daftar pustaka}

Ahmad bin Hambal, 1999M, Musnad Al-Imam Ahmad bin Hambal, Beirut, Muassah Ar-Risalah. Apelesl Lexi Lonto,Theodorus Pangalila, 2016, Etika Kewarganegaraan. Yogyakarta, Penerbit Ombak.

Bittner, 1980, mass Communication an Introduction Engelwood Cliffs, London, New Jersey.

Cristian Funch, 2017, Social Media A Crotical Introduction, London, SAGE

Publications.

Departemen Agama RI. 2004, Al-Qurran Dan Tafsirnya, Jakarta, Depag RI.

Elvinaro Ardianto, Lukiati Kumala, Siti Karnilah, 2014, Komunikasi Massa Suatu Pengantar,

Bandung, Simbiosa Rekatama Media.

H. Mahi M. Hikmat, 2018, jurnalistik literaty journalism, Jakarta, pranadamedia.

Hefni Harjani, 2015, komunikasi islami, Jakarta, Penerbit Prenada media. 
Prinsip Komunikasi Islam Sebagai Etika Bermedia Sosial

Muhammad Ilmi Saggaf, Muhammad Wildan Arif Amrullah, Muhammad Habibie, Khairul Atqiya

Ignatius Haryanto, Jurnalisme Era Digital Tantangan Industry Abad 21, (Jakarta: Kompas Media Nusantara, 2014), hal. 10.

Iriantara Iriantara, 2011, Media Relations Konsep, Pendekatan, praktik. Bandung, Simbiosa Rekatama Media.

Instagram, infobmkg, di akses 13:47, 15 oktober 20

Khalil Syukur, 2007, komunkasi Islam, Bandung, Citapustaka Media.

Kismiyati, 2010, Filsafat Dan Etika, Bandung, widya padjajaran, 2010.

K. Bertens, 1993, Etika, Jakarta, PT Gramedia Pustaka Utama.

Kominfo.go.id, Pengguna internet di Indonesia 63 juta orang, di akses 26 oktober 2018, pukul 11:11 WIB.

Komisi Fatwa Majlis Ulama Indonesia, nomer 24 tahun 2017, tentang, Hukum dan Pedoman Bermuamalah Melalui Media sosial.

Mulyana Dedy, perkembangan Teknologi Informasi: New Media, Jurnal Umum Unpas, Terbitan Mei 2014.

Morisan, 2013, Teori Komunikasi Individu Hingga Massa, Jakarta, Penerbit Prenada Media Group

Muslim bin Al-Hajjaj An-Naysaburi, Al-jami al-Sahih Al-Musamma Sahih Muslim, Beirut, Dar al-Jail.

Muhammad bin Ahmad Al-Qurthubi,1964, al-jami li-Ahkam Al-qurran,(Kairo, Dar-Al kutub AlMishriyyah.

Muhammad Bin Ismail Al-Bukhari Al-ju fi, 1422, Shahih Al-Bukhari, Dar Thuq-Annajah.

Muhammad bin Habban, Sohih Ibnu Habban, Beirut: muassah Ar-risalah.

Muhammad bin Isa, Al-jami As-shohih Sunan Al-tirmidzi, Beirut: Darul Al-ihya At Turas Al Arabi.

Muhammad bin futuh Al-Hamidi,2002, Al-jam,u Baina Sohihaini Al-bukhari wa Muslim, beirut: daru Ibnu Hazm.

Nasrullah Rulli, 2016, media sosial perspektif komunikasi, budaya dan sosioteknologi, Bandung, Simbiosa Rekatama Media.

Sardar Zianuddin, 1991, Rekayasa masa depan peradaban Muslim, Bandung, Penerbit Mizan.

Suprato Tommy, 2009, Pengantar Teori dan Manajemen Komunikasi, Yogyakarta, Penerbit Medpress,

Syah Sirikit, 2011, Rambu rambu Jurnalistik dari undang-undang hingga hati nurani.

Yogyakarta, Pustaka pelajar. 
Wilbur Schramm,1995, the process Effect Of mass Comunication, Urbana, University Of Ilinois.

Tambaruka Apriadi, 2013, Literasi Media Cerdas Bermedia Khalayak Media Massa, Jakarta, Raja Grafindo

Tonny Ilham Prayogo, et al., “Ibn Rushd's Strategic Analysis on Mutakallimin's Idea of God's Existence", ICLLE 2019, July 19-20, Padang, Indonesia. http://dx.doi.org/10.4108/eai.19-72019.2289534.

Wilbur Schramm, 1995, the process Effect Of mass Comunication, Urbana, University Of Ilinois. Instagram, infobmkg, di akses 13:47, 15 oktober 20

KOMINFO RI, berita Hoax bulanan oktober 2018. 